\title{
Plasma reference value of heart-type fatty acid-binding protein, the earliest available plasma biomarker of acute myocardial infarction
}

\author{
Jan F. C. Glatz ${ }^{1 *}$, Ron Mohren ${ }^{2}$ \\ ${ }^{1}$ Department of Genetics and Cell Biology, Cardiovascular Research Institute Maastricht (CARIM), Maastricht University, Maastricht, \\ The Netherlands; ${ }^{*}$ Corresponding Author: glatz@maastrichtuniversity.nl \\ ${ }^{2}$ FABPulous B.V., Oxfordlaan 55, Maastricht, The Netherlands
}

Received 22 May 2013; revised 23 June 2013; accepted 15 July 2013

Copyright (C) 2013 Jan F. C. Glatz, Ron Mohren. This is an open access article distributed under the Creative Commons Attribution License, which permits unrestricted use, distribution, and reproduction in any medium, provided the original work is properly cited.

\begin{abstract}
More rapid triaging of patients suspected for acute myocardial infarction (AMI) is needed to facilitate early initiation of appropriate therapy in patients with AMI and to exclude low-risk patients who can safely be sent home. Heart-type fatty acid-binding protein (H-FABP) is established to be the earliest available plasma marker for AMI diagnosis. There is a paucity of data on circulating levels of H-FABP in the general population. In this study we applied a H-FABP immunoassay with improved analytical performance to assess plasma H-FABP reference values in a relatively large group $(n=443)$ of healthy subjects aged 18 - 69 y. Mean ( \pm SD) plasma $\mathrm{H}$ FABP concentration was $1.7 \pm 0.9 \mathrm{ng} / \mathrm{mL}$, with somewhat higher values found in males than in females. Plasma H-FABP also increases with age, as previously reported. The 99th centile was obtained for subjects aged 41 - 69 years and amounted to $5.6 \mathrm{ng} / \mathrm{mL}$.
\end{abstract}

Keywords: Acute Coronary Syndromes; Acute Myocardial Infarction; H-FABP; Plasma Reference Value

\section{INTRODUCTION}

Biochemical markers of myocardial injury are important tools for the diagnosis of patients with suspected acute myocardial infarction (AMI), especially in those cases in which electrocardiographic (ECG) changes are equivocal or absent. Therefore, these so-called cardiac markers are included in the diagnosis of acute coronary syndromes (ACS) [1]. In recent years, attention has shifted to those cardiac markers that allow an earlier and more appropriate diagnosis of patients in order to install the proper therapy as early as possible. Heart-type fatty acid-binding protein (H-FABP) is established to be the earliest available plasma marker for ACS detection [2]. For triaging at presentation of patients suspected of ACS, H-FABP performs better than cardiac troponin $\mathrm{T}(\mathrm{cTnT})$ [3], and in the early hours after onset of symptoms even better than high-sensitivity cTnT [4]. In addition, HFABP predicts long-term mortality and re-infarction in patients with suspected ACS who are cTnT negative [5]. It has been suggested that the combination of H-FABP and $\mathrm{cTnT}$ would provide an optimal sensitivity and negative predictive value for ACS detection [3,6,7].

Reports on plasma H-FABP reference values are scarce $[2,8-10]$. The reported upper reference limit, i.e., the 99th percentile of the plasma H-FABP reference concentration, ranges from $5 \mathrm{ng} / \mathrm{mL}$ [9] to $9 \mathrm{ng} / \mathrm{mL}$ [10]. The aim of the present work was to apply an ELISA with high sensitivity (detection limit $0.25 \mathrm{ng} / \mathrm{mL}$ ) to assess $\mathrm{H}-\mathrm{FABP}$ reference values in a relatively large group $(\mathrm{n}=$ 443) of subjects aged $18-69$ years.

\section{MATERIALS AND METHODS}

Plasma samples were obtained from 443 apparently healthy individuals (229 males, age $18-68$ years, and 214 females, age 18 - 69) visiting the blood bank in Maastricht (Sanquin), the Netherlands, or in Leuven, Belgium. EDTA was used as anti-coagulant. Plasma samples were stored at $-20^{\circ} \mathrm{C}$ and H-FABP was analyzed within a maximum of 4 weeks after storage. The study was approved according to the applicable regulations in the Netherlands and Belgium.

Heart-type FABP was measured using a direct noncompetitive (sandwich-type) enzyme-linked immunosor- 
bent assay, essentially as developed by Wodzig et al. [11] but with adaptations to increase its accuracy especially at lower H-FABP concentrations [2]. The monoclonal antibodies used were developed and characterized by Roos et al. [12]. The capture antibody (67D3) was conjugated to biotin and the detector antibody (66E2) to horseradish peroxidase (HRP). Samples were measured by incubating a streptavidin-coated ELISA plate with a mixture of both antibody conjugates and the plasma sample.

Recombinant human H-FABP was produced by UProtein Express (Utrecht, the Netherlands) and used as calibrator. A codon optimized sequenced human H-FABP gene was transformed in BL21(DE3)Star-pLys S bacteria. $\mathrm{H}-\mathrm{FABP}$ protein was purified using gel filtration and ion-exchange chromatography to $>99 \%$ purity.

The detection limit of the assay was $0.25 \mathrm{ng} / \mathrm{mL}$, and the detection range was up to $32 \mathrm{ng} / \mathrm{mL}$. The interassay coefficient of variation (CV) was determined with pooled plasma samples of 5, 12 and $25 \mathrm{ng} / \mathrm{mL}$ to amount to $4 \%$, $5 \%$ and $7 \%$, respectively.

Data are presented either as medians, with 25 and 75 percentiles in parentheses, or as mean $\pm \mathrm{SD}$ as indicated. Parametric 99th centile value was calculated after loga- rithmic transformation without removal of outliers. Ten samples showed values below the detection limit of 0.25 $\mathrm{ng} / \mathrm{mL}$ and were assigned the detection limit; of these, two samples were from subjects in the age category 41 69 years from which the 99 th centile was calculated.

\section{RESULTS}

Table 1 provides the median plasma concentrations of H-FABP, together with 25 and 75 percentile values, for different age groups. For the entire group of 443 presumed healthy individuals (age $18-69$ y) the mean $( \pm \mathrm{SD})$ $\mathrm{H}-\mathrm{FABP}$ plasma concentration was $1.7 \mathrm{ng} / \mathrm{mL}( \pm 0.95)$. In general, H-FABP concentrations are somewhat higher for male $(1.9 \pm 0.9 \mathrm{ng} / \mathrm{mL})$ compared to female subjects $(1.5 \pm 0.9 \mathrm{ng} / \mathrm{mL})$ and increase with age although this increase is less pronounced in male than in female subjects (Table 1).

To define the 99th centile value for plasma H-FABP data for subjects 41 - 69 years were used (253 subjects), as these represent the age group from which the majority of patients with suspected ACS enter the hospital. The 99th centile found is $5.6 \mathrm{ng} / \mathrm{mL}$ (Figure 1).

Table 1. Median plasma concentrations (with 25 and 75 percentiles) of H-FABP (in $\mathrm{ng} / \mathrm{mL}$ ) in apparently healthy men and women of different age groups.

\begin{tabular}{cccccc}
\hline \multicolumn{5}{c}{ Age group (year) } \\
\hline \multirow{2}{*}{ Female } & $18-30$ & $31-40$ & $41-50$ & $51-60$ & $61-70$ \\
Male & $1.0(0.6-1.3)$ & $1.2(1.0-1.6)$ & $1.6(1.4-1.8)$ & $1.6(1.4-2.3)$ & $2.2(1.8-2.6)$ \\
\hline
\end{tabular}

Data are expressed as median ( 25 and 75 percentile) for 28 - 40 subjects per age group and per sex.

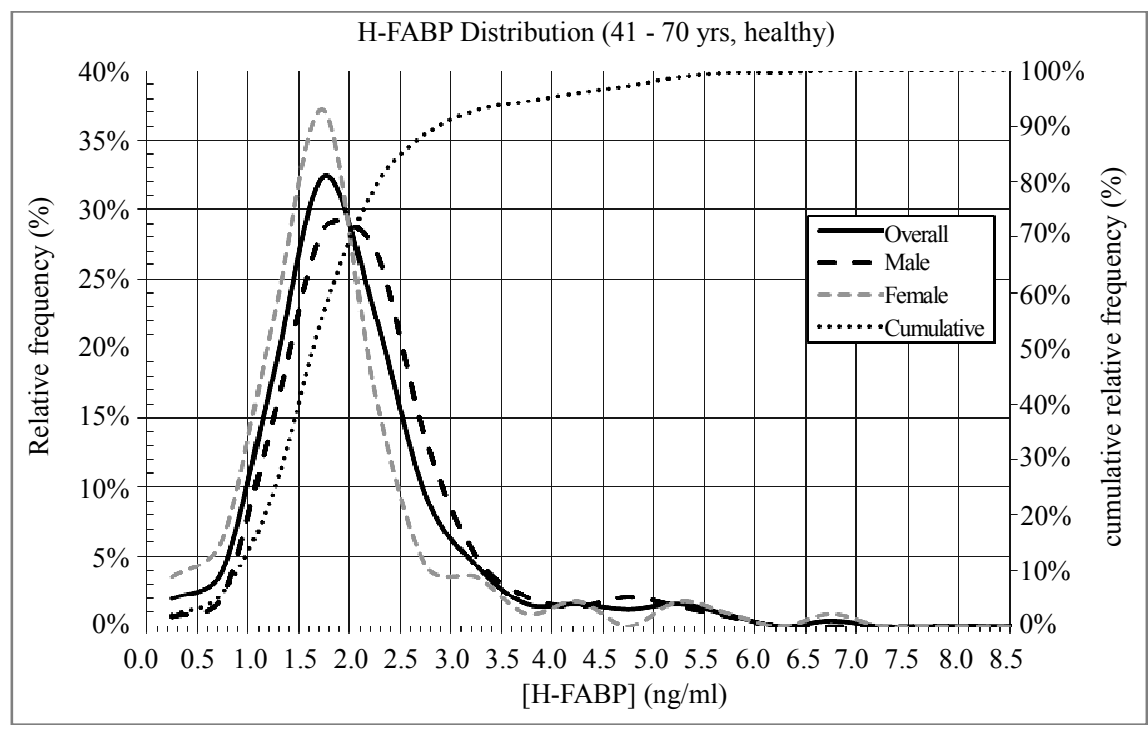

Figure 1. Distribution of plasma H-FABP in apparently healthy volunteers of $41-70$ years. Data are shown for females $(n=113)$ and males $(n=140)$ separately and combined. The 99 th centile is $5.6 \mathrm{ng} / \mathrm{mL}$. 


\section{DISCUSSION}

The observed mean plasma H-FABP concentration, which was measured with an assay with improved analytical performance, is similar to previously published values for apparently healthy volunteers $[2,8-10]$. We also confirm the increase of plasma H-FABP with age and higher values for male than for female subjects $[2,8]$. However, a previous study of a UK population sample reported no significant gender differences, although a tendency to higher values in male subjects was noted [9].

The 99th centile value defined in our report $(5.6 \mathrm{ng} / \mathrm{mL})$ agrees to that reported by Bathia et al. [9] which is lower than that reported by others $[8,10]$. These discrepancies may result, at least in part, from the use of distinct immunoassays for H-FABP, as the various investigators applied either the Randox Evidence Investigator assay [9], the Randox immunoturbidimetric assay [10], or the Markit-M H-FABP assay from Dainippon Pharmaceutical Ltd. [8]. It has been suggested that the difference between assays is due to a calibration difference rather than a difference in antibody specificity [9]. Therefore, an international H-FABP standard will be needed to make sure that H-FABP become more widely used in clinical practice.

Various clinical studies have assessed the diagnostic performance of H-FABP in the early diagnosis of AMI and the receiver operating characteristic (ROC) curve analyses have reported cut-off levels for a positive test ranging from 3.3 to $12 \mathrm{ng} / \mathrm{mL}[6,13,14]$. The 99 th centile value of $5.6 \mathrm{ng} / \mathrm{mL}$ agrees with this range of reported cut-off levels.

It should be noted that plasma H-FABP can be quantitatively determined in the full normal population. In contrast, for troponin $\mathrm{T}$ (and also troponin I), the assay detection limit is much closer to the 99th centile value so that troponin levels cannot be quantitatively determined in a larger part of the normal population [15]. These differences in analytical performance between H-FABP and TnT add to the potential of H-FABP for risk stratification in patients suspected for ACS.

\section{REFERENCES}

[1] Hamm, C.W., Bassand, J.-P., Agewall, S., Bax, J., Boersma, E., Bueno, H., Caso, P., Dudek, D., Gielen, S., Huber, K., Ohmann, M., Petrie, M.C., Sonntag, F., Sousa Uva, M., Storey, R.F., Wijns, W. and Zahger, D. (2011) ESC guidelines for the management of acute coronary syndromes in patients presenting without persistent ST-segment elevation. European Heart Journal, 32, 2999-3054. doi:10.1093/eurheartj/ehr236

[2] Pelsers, M.M.A.L., Chapelle, J.P., Knapen, M., Vermeer, C., Muijtjens, A.M.M., Hermens, W.T. and Glatz, J.F.C. (1999) Influence of age and sex and day-to-day and within-day biological variation on plasma concentrations of fatty acid-binding protein and myoglobin in healthy sub- jects. Clinical Chemistry, 45, 441-443.

[3] Haltern, G., Peiniger, S., Bufe, A., Reiss, G., Gülker, H. and Scheffold, T. (2010) Comparison of usefulness of heart-type fatty acid binding protein versus cardiac troponin $\mathrm{T}$ for diagnosis of acute myocardial infarction. American Journal of Cardiology, 105, 1-9. doi:10.1016/j.amjcard.2009.08.645

[4] Kurz, K., Giannitsis, E., Becker, M., Hess, G., Zdunek, D. and Katus, H.A. (2011) Comparison of the new high sensitivity cardiac troponin $\mathrm{T}$ with myoglobin, h-FABP and cTnT for early identification of myocardial necrosis in the acute coronary syndrome. Clinical Research in Cardiology, 100, 209-215. doi:10.1007/s00392-010-0230-y

[5] Viswanathan, K., Kilcullen, N., Morrell, C., Thistlethwaite, S.J., Sivananthan, M.U., Hassan, T.B., Barth, J.H. and Hall, A.S. (2010) Heart-type fatty acid-binding protein predicts long-term mortality and re-infarction in consecutive patients with suspected acute coronary syndrome who are troponin-negative. Journal of the American College of Cardiology, 55, 2590-2598. doi:10.1016/i.jacc.2009.12.062

[6] Lippi, G., Mattiuzzi, C. and Cervellin, G. (2013) Critical review and meta-analysis on the combination of hearttype fatty acid binding protein (H-FABP) and troponin for early diagnosis of acute myocardial infarction. Clinical Biochemistry, 46, 26-30.

doi:10.1016/j.clinbiochem.2012.10.016

[7] Ruff, C.T., Bonaca, M.P., Kosowsky, J.M., Conrad M.J., Murphy, S.A., Jarolim P., Donahoe, S.M., O'Donoghue, M.L. and Morrow, D.A. (2013) Evaluation of the diagnostic performance of heart-type fatty acid binding protein in the BWH-TIMI ED chest pain study. Journal of Thrombosis and Thrombolysis, in press.

doi:10.1007/s11239-013-0870-7

[8] Niizeki, T., Takeishi, Y., Takabatake, N., Shibata, Y., Konta, T., Kato, T., Kawata, S. and Kubota, I. (2007) Circulating levels of heart-type fatty acid-binding protein in a general Japanese population: Effects of age, gender and physiological characteristics. Circulation Journal, 71, 14521457. doi:10.1253/circj.71.1452

[9] Bathia, D.P., Carless, D.R., Viswanathan, K., Hall, A.S. and Barth, J.H. (2009) Serum 99th centile values for two heart-type fatty acid binding protein assays. Annals of Clinical Biochemistry, 46, 464-467. doi:10.1258/acb.2009.009055

[10] Carless, D.R., Wnek, M., Knox, C., Harrison, K.R., Calder, N., Hall, A.S. and Barth, J.H. (2013) Clinical and analytical evaluation of an immunoturbidimetric hearttype fatty acid-binding protein assay. Scandinavian Journal of Clinical \& Laboratory Investigation, 73, 48-53. doi:10.3109/00365513.2012.734396

[11] Wodzig, K.W.H., Pelsers, M.M.A.L., Van der Vusse, G.J., Roos, W. and Glatz, J.F.C. (1997) One-step enzymelinked immunosorbent assay (ELISA) for plasma fatty acid-binding protein. Annals of Clinical Biochemistry, 34, 263-268.

[12] Roos, W., Eymann, E., Symannek, M., Duppenthaler, J., Wodzig, K.W.H., Pelsers, M.M.A.L. and Glatz, J.F.C. (1995) Monoclonal antibodies to human heart fatty acid- 
binding protein. Journal of Immunological Methods, 183, 149-153. doi:10.1016/0022-1759(95)00043-A

[13] Bruins Slot, M.H.E., Reitsma, J.B., Rutten, F.H., Hoes, A.W. and Van der Heijden, G.J.M.G. (2010) Heart-type fatty acid-binding protein in the early diagnosis of acute myocardial infarction: A systematic review and metaanalysis. Heart, 96, 1957-1963.

doi:10.1136/hrt.2010.208272
[14] Viswanathan, K., Hall, A.S. and Barth, J.H. (2012) An evidence-based approach to the assessment of heart-type fatty acid binding protein in acute coronary syndrome. Clinical Biochemistry Review, 33, 3-11.

[15] Tate, J.R. (2008) Troponin revisited 2008: Assay performance. Clinical Chemistry and Laboratory Medicine, 46, 1489-1500. doi:10.1515/CCLM.2008.292 